\title{
ON MAGNETIC OBSERVATIONS IN THE AZORES.
}

By Aleert, Prince of Monaco.

After having perceived the capital importance of the Azores, from their geographical position, for the establishment of meteorological observatories with a view to weather predictions, I thought that these observatories might be of service to other branches of science. For instance, the communications of Messrs. Neumayer, Mascart, von Bezold, and other eminent meteorologists, to the International Conference of

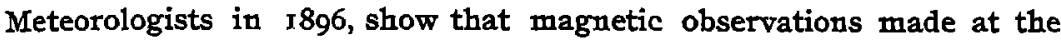
Azores would offer the following advantages:(I) A situation near latitude $40^{\circ} \mathrm{N}$. (page 22); (2) remoteness from the permanent causes of perturbation of actual magnetic observation, such as electric lighting tramways, and other applications of electricity; and (3) a geographical position intermediate between Europe and America, capable of furnishing most useful indications for the comparison of the magnetic curves obtained in these two parts of the world (pp. 36 and 9o).

The examination of these considerations and different interviews which I had with M. Mascart, director of the Bureau Centrale Méteorologique of France, convinced me of the advantage which would be gained if Captain Chaves, director of the Meteorological Observatory of Ponte Delgada, came to Europe to study the practical details of the magnetic service there. I therefore communicated my ideas to the Portuguese Government, who recalled Captain Chaves to undertake a mission in this sense.

Captain Chaves, after having finished his studies at the observatory of St. Maur under the enlightened direction of $M$. Moureaux, has pointed out to me the importance of taking the present opportunity of magnetically reconnoitering the archipelago, as a preliminary to the definitive installation of the observatory. This would be useful, not only to determine the value of the different magnetic elements, till now almost unknown, ${ }^{1}$ but besides, to determine in the island of St. Michael, which appears likely to present conditions favorable to the installation of the central observatory of the Azores, the locality most suitable for the combined services of meteorology and magnetism.

Feeling certain that the views of Captain Chaves are just, and well knowing his competence, being also aware that the Portuguese Geodetic Commission finished last year the survey of the island of St. Michael, and that this year it will finish the survey of the neighboring island of Santa Maria, I have resolved to undertake the charge of the above-mentioned magnetic reconnaissance.

1 In fact, even the value of the declination, one of the most important magnetic elements, is given for one and the same place, Horta in Fayal, with differences amounting to $I^{\circ} 22^{\prime}$ in an interval of two years. Thus Preston in I889 gives $25^{\circ} 52^{\prime}$, and the Acorn in 1891 gives $24^{\circ} 30^{\prime}$. 
With this end I am now having the necessary instruments constructed; and I announce to the International Commission that I hope to be able to put Captain Chaves in the position to be able to commence the magnetic reconnaissance of the Azores towards the month of April of next year.

SUR LE MOUVEMENT DIURNE DU PÔLE NORD D'UN BARREAU MAGNÉTIQUÉ SUSPENDU PAR LE CENTRE DE GRAVITÉ.

Par J. B. CapeliLo.

En combinant les variations diurnes de l'inclinaison avec celles de la declinaison, sur un plan perpendiculaire à la direction de l'inclinaison, résulte une courbe fermée.

Les variations ou écarts de l'inclinaison sont positives vers le sud, et celles de la declinaison positives vers l'ouest.

Il faut avertir que les écarts de la déclinaison doivent etre multipliés par le cosinus de l'inclinaison, afin de les projeter sur un plan perpendiculaire à la même inclinaison.

Il est interressant de comparer ces courbes obtenues en divers points ou stations du globe.

La Ière Planche contient les courbes de Kew, Paris (Parc St Maur), Perpignan, et Lisbonne en I 894 et 1895 .

Les courbes de Kew et de Lisbonne sont deduites des jours tranquils (cinq jours choisis à chaque mois), celles de Paris et de Perpignan sont deduites de tous les jours.

I a $2^{\text {eme }}$ Planche contient les courbes de Lisbonne et de Kew de I896; de St Petersbourg (1873-85) et des jours dits normaux, et celle de Lisbonne de 1864-72, excepté les perturbations, d'après la méthode du Géneral Sabine.

La $3^{\text {ème }}$ Planche contient les variations diurnes du Bifilaire, du vertical et de l'inclinaison a Lisbonne et Kew, 1894-95-96.

Retournant à la I ère P1. on remarque que les courbes des observatoires plus au nord sont plus rondes que celles des autres situés plus au sud.

Ainsi, Kew de 1894 et 1895 affectent la figure elliptique; ensuite vient Paris avec la forme plus allongee; Perpignan encore plus étroite et mince du côté de l'ouest, et finalement Lisbonne, dont les courbes sont plus larges du côté de l'ouest, et minces de l'est, affectant la forme d'un $\infty$.

On voit un autre fait plus remarquable. Tandis que dans les courbes de Kew, Paris, et Perpignan le mouvement vers l'ouest, du matin au soir, est par le sud du point moyen, à Lisbonne il est par le nord, de façon que le mouvement est rétrograde en regard dés autres.

Pour mieux faire ressortir cette circonstance, nous avons dans la ${ }_{2}$ ème P1. donne les courbes de Kew et de Lisbonne pour l'annee I 896 . 